\title{
Anticancer Activity of Bispidinone Derivative by Induction of Apoptosis
}

\author{
Man Gi Lee $e^{2, *}$ and Ryong Kwon ${ }^{1, ;, * *}$ \\ ${ }^{I}$ Department of Biomedicinal Chemistry, Inje University, Gimhae 50834, Korea \\ ${ }^{2}$ Department of Sports Healthcare, Inje University, Gimhae 50834, Korea
}

The present study was carried out to investigate the possibility that bispidinone derivative makes anticancer drug availability to human cervical carcinoma cell. The $\mathrm{B} 8$ has the lowest $\mathrm{IC}_{50}$ value among $\mathrm{B} 8, \mathrm{~B} 9$ and $\mathrm{B} 10$ which are bispidinone analogue with bromide. According to cytotoxic test through WST-8 assay, B8 shows the most magnificent cytotoxicity effectiveness with $76 \mu \mathrm{M}$ of $\mathrm{IC}_{50}$ value. In human cervical carcinoma cell treated with $\mathrm{B} 8$, it noticeably controlled cellular multiplication by increase of concentration and time. Furthermore, morphological changes like cellular shrink, disruption and nuclear condensation, feature of apoptosis, are observed. Annexin V-FITC/PI double staining assay test proved that B8 can cause apoptosis. Moreover, after treatment with $76 \mu \mathrm{M}$ of B8, flow cytometry analysis shows that increase of active oxygen species are induced and membrane potential in mitochondria is decreased. Manifestation of Bcl-2 family and caspase cascades protein provides evidence that B8 induces apoptosis through mitochondria and caspase-related pathway. Taken together, we suggested that B8 reduced membrane potential in mitochondria and induce apoptosis through the pathway depended on mitochondria and caspase.

Key Words: Bispidinone, Apoptosis, Mitochondria membrane potential, Reactive oxygen species, Anticancer activity

\section{서 론}

세포 사멸은 세포가 죽음에 이르는 방법 중의 하나로 필요하지 않은 세포나 이상이 있는 세포를 제거하여 생명 체의 생리적 균형을 유지하게 한다. 세포사멸은 크게 내 부 경로(intrinsic pathway)와 외부 경로(extrinsic pathway)에 의해 아주 세밀하게 조절되는 두 가지 메커니즘을 가지 고 있는데, 내부 경로의 경우 저산소증이나 DNA의 손상 등에 의해 발생한다(Ziegler and Kung, 2008). 또한 내부 경로와 관련된 미토콘드리아의 중요한 역할 중 하나는 DNA가 손상을 받았을 경우 미토콘드리아 막(Mitochondria membrane potential, $\mathrm{MMP}$ )이 붕괴되어 세포질로 cytochrome c가 방출되고 이것은 Apaf-1 (apoptotic protease activating factor 1) protein과 결합하여 apoptosome을 형성한다(Wang and Youle, 2009). Apoptosome의 형성은 procaspase를 caspase (caspase-3, -7, -9)로 활성화시키는 역할을 하여 apoptosis 가 일어나게 되며 그 외에도 여러 가지 단백질의 생성은 Bcl-2 family, Bax에 의해 조절된다(Pathak et al., 2009). 외 부 경로(extrinsic pathway)의 경우 death signal이 fas death receptor 통해 procaspase-8을 caspase-8로 활성화시키고 계 속적으로 caspase-3을 활성화하여 세포 사멸이 일어나게 된다(Lobrich and Jeggo, 2007).

한편 과산화수소(hydrogen peroxide: $\mathrm{H}_{2} \mathrm{O}_{2}$ )나 초과산화 이온(superoxide anion: $\mathrm{O}_{2}^{-}$), 수산화 라디칼(hydroxyl radical: $\cdot \mathrm{OH})$ 과 같은 활성산소(reactive oxygen species, ROS)들은 세포 생존과 죽음을 조절하는 세포 내 신호 전달 경로에 서 중요한 역할을 한다(Mine et al., 2001; LeBras et al., 2005).

Received: October 29, 2020 / Revised: December 24, 2020 / Accepted: December 28, 2020

* Professor, ${ }^{* *}$ Researcher.

${ }^{\dagger}$ Corresponding author: Ryong Kwon. Department of Biomedicinal Chemistry, Inje University, Gimhae 50834, Korea. Tel: +82-10-3044-7412, Fax: +82-55-320-3219, e-mail: kwon7450@naver.com

(C) The Korean Society for Biomedical Laboratory Sciences. All rights reserved.

(C) This is an Open Access article distributed under the terms of the Creative Commons Attribution Non-Commercial License (http://creativecommons.org/licenses/by-nc/3.0/) which permits unrestricted non-commercial use, distribution, and reproduction in any medium, provided the original work is properly cited. 
산화적 스트레스와 세포 사멸 간에 밀접한 관계가 있음 이 보고되었다(Fleury et al., 2002). 활성산소가 많이 존재하 면 세포 사멸이 일어나고 작게 존재하면 세포의 생존과 증식을 향상시킨다(Murray, 1994; Pucci et al., 2000). 세포 사 멸의 유도에 미토콘드리아의 역할이 중요하다(Limon et al., 2000). 활성산소는 미토콘드리아 막 전위를 감소시키고 cytochrome c를 방출하여 caspase들을 활성화시켜서 세포 사멸이 일어나게 한다(Chan et al., 2003; Jiang et al., 2012).

천연 알칼로이드인 sparteine과 구조적으로 유사한 3,7diazabicyclo[3.3.1]nonan-9-ones (bispidines)은 항부정맥과 무 통각, 항균활성 등과 같은 생물학적 중요성 때문에 입체 화학과 이것의 합성에 많은 관심을 가진다(Jaiprakash et al., 2014). 또한, bispidines은 K opioid 수용체에 높은 친화 력과 선택성을 나타내는 것이 밝혀졌다(Aline et al., 2019). Bispidines의 특이한 구조는 이론적인 관점에서 뿐만 아니 라, 특히 2,4,6,8-tetraaryl-3,7-diazabicyclo[3.3.1]nonan-9-one (bispidinone)은 4 개 aryl 기의 존재 때문에 많은 관심을 가 진다. 방사성 구리 동위원소에 대한 진단 $\left.{ }^{64} \mathrm{Cu}\right)$ 또는 치료 $\left({ }^{67} \mathrm{Cu}\right)$ 를 위한 chelate 리간드로서 bispidines이 많이 이용되 고 있다(Kraus et al., 2009). Bispidinone의 항암활성에 대한 작용기전과 관련된 생물학적 특성은 많이 연구되지 않 았다.

본 연구에서 다양한 알칼로이드 분자 구조를 갖는 bispidinone 화합물(mother compounds)에서 벤젠의 ortho, meta, para 자리에 브롬으로 치환하여 합성한 $\mathrm{B} 8, \mathrm{~B} 9, \mathrm{~B} 10$ 중 $\mathrm{B} 8$ (2,4,6,8-tetrakis(2-bromophenyl)-3,7-diazabicyclo[3.3.1]nonan9-one)의 독성이 가장 강하다는 것을 확인하였다(Table 1). 따라서 본 연구에서는 B8에 의해 유도되는 세포사멸 현 상과 자세한 작용기전을 밝히고자 한다.

\section{재료 및 방법}

\section{화학제품}

Phosphate-buffered saline (PBS, $\mathrm{pH}$ 7.4)와 dimethyl sulfoxide (DMSO)는 Sigma-Aldrich Chemical Co. (St. Louis, MO, USA) 에서 구매하였고 Annexin-FITC kit와 세포사멸에 대한 세 포주기 분석의 PI/RNase 염색용액은 BD Pharmingen (San Diego, CA, USA), Eagle's minimum essential medium (EMEM), penicillin-streptomycin, Fetal bovine serum (FBS)은 HyClone Laboratories, InC. (Logan, UT, USA), 그리고 cell counting Kit-8은 Dojindo Molecular Technologies, InC. (Osaka, Japan) 에서 얻었으며 trypsin-EDTA는 Gibco-BRL (Invitrogen Co.,
USA)에서 구매하였다.

\section{세포배양}

American Type Culture Collection (ATCC, Manassas, VA, USA)에서 얻은 HeLa cells을 Fetal bovine serum과 $1 \%$ penicillin-streptomycin 넣어 만든 $\mathrm{EMEM}$ 으로 $37^{\circ} \mathrm{C}(5 \%$ $\mathrm{CO}_{2}$ )의 습한 환경에서 배양하였다.

\section{Bispidinone 용액들의 제조}

2,4,6,8-tetrakis(2-bromophenyl)-3,7-diazabicyclo[3.3.1]nonan9-one (B8)과 2,4,6,8-tetrakis(3-bromophenyl)-3,7-diazabicyclo [3.3.1]nonan-9-one (B9), 2,4,6,8-tetrakis(1-bromophenyl)-3,7diazabicyclo[3.3.1]nonan-9-one (B10)은 Dr. D. H. Park의 실 험실에서 얻었으며, bispidinone 용액은 dimethyl sulfoxide (DMSO)에 녹여 만들었고 추가 희석은 실험 직전에 실행 하였다.

\section{세포의 생존 및 증식 분석}

HeLa cells을 96-well plate의 각 well에 배지 $\mathrm{mL}$ 당 $5 \times$ $10^{4}$ 의 값으로 계산하여 접종 후 배양하는 동안 media를 갈아 주었으며 $\mathrm{B} 8$ 을 다양한 농도로 처리한 후 48시간 동 안 배양하였다. 또한 CCK-8 시약 $10 \mu \mathrm{L}$ 를 각 well에 넣어 추가로 2 시간 동안 배양하였고 세포 생존율은 WST- 8 를 사용하여 측정하였으며, 살아있는 세포의 optical density 는 multi-microplate reader (synergy HT, Bio-Tek ${ }^{\circledR}$ 로 $450 \mathrm{~nm}$ 에서 흡광도를 측정하였다. HeLa cells의 proliferation assay 의 경우 96-well plate에 $\mathrm{mL}$ 의 배지당 $5 \times 10^{4}$ 으로 seeding 하고 $\mathrm{B} 8$ 을 $76 \mu \mathrm{M}$ 농도로 처리 후 다양한 시간 변화에 대 한 흡광도를 측정하였으며, 각각의 실험은 3회 이상 반복 하였다.

\section{세포사멸의 형태학적 분석}

HeLa cells을 6-well plate에 $2 \times 10^{5}$ cell/well 농도로 넣은 후 밤새 부착시키고, cells에 24시간, 48시간 동안 $\mathrm{B} 8$ (약 $75 \mu \mathrm{M}$ )과 함께 처리하였다. 처리되지 않은 wells은 대조군 으로서 $\mathrm{DMSO}(<0.1 \%)$ 와 동등한 양을 넣고 측정하였다. 또한 세포에 대한 검사와 형태학적 변화는 Nikon Phase Contrast-2와 ELWD 0.3 invert microscope로 촬영하였다.

\section{Annexin V-FITC/PI를 이용한 세포사멸 분석}

$\mathrm{HeLa}$ 세포를 $60 \mathrm{~mm}$-dish에 $1 \times 10^{5}$ 세포 $/ \mathrm{mL}$ 의 농도로 가하여 24 시간 배양한 후에 $76 \mu \mathrm{M}$ 의 $\mathrm{B} 8$ 을 포함한 새로운 
배지로 각각 교체한 후 각기 다른 시간대에 따라 트립신 처리(trypsinization)를 이용하여 세포를 모은다. 그리고 원 심분리기를 이용하여 세포 부유액을 인산완충용액(PBS)으 로 세척한 후 세포 펠렛(pellet)을 $100 \mu \mathrm{L}$ 의 결합완충용액 (binding buffer) 에 부유시킨 다음 $5 \mu \mathrm{L}$ 의 annexin V-FITC와 $10 \mu \mathrm{L}$ 의 PI $(50 \mu \mathrm{g} / \mathrm{mL})$ 를 가한 후 실온 $\left(15 \sim 25^{\circ} \mathrm{C}\right)$ 의 어두운 곳에서 15 분간 염색하였다. 그리고 이 세포들은 $488 \mathrm{~nm}$ 의 파장에서 FACScalibur 유세포분석기(FACScalibur-기기모델, $\mathrm{BD}$ Bioscience)를 이용하여 측정하고 $\mathrm{BD}$ Instruments에서 제공된 프로그램으로 분석하였다.

\section{세포 내 활성산소 측정}

활성산소 종의 생성은 형광 지시약인 2,7-dichlorodihydrofluorescein $\left(\mathrm{H}_{2} \mathrm{DCFDA}\right)$ 를 사용하여 측정하였다. $\mathrm{H}_{2} \mathrm{DCFDA}$ 는 ROS의 생성을 통해 높은 녹색 형광물질인 2,7-dichlorofluorescein $(\mathrm{DCF})$ 로 산화한다. B8 $(76 \mu \mathrm{M})$ 과 함께 처리 하거나 처리하지 않은 HeLa cells $\left(1 \times 10^{5}\right.$ cells in a $60 \mathrm{~mm}$ dish)을 트립신 처리 후 원심분리하여 수집하였다. 시료를 차가운 $\mathrm{PBS}$ 로 세척하고 $37^{\circ} \mathrm{C}$, 암실에서 30 분 동안 $2 \mu \mathrm{L}$ 의 $\mathrm{H}_{2} \mathrm{DCFDA}$ 를 처리하여 염색하였다. 상대적 형광강도는 FACSCalibur flow cytometer으로 측정하였고, $520 \mathrm{~nm}$ 의 흡광
도와 FL-1 channel (green)로 맞추어 Cell Quest pro software 로 분석하였다.

\section{미토콘드리아 막 전위 $(\triangle \Psi \mathrm{m})$ 의 측정}

미토콘드리아 막 전위의 변화는 형광 probe인 rhodamine 123 (RH-123; Molecular Probes)을 이용하여 측정하였다. B8 $(76 \mu \mathrm{M})$ 을 처리하거나 처리하지 않은 HeLa cells $(1 \times$ $10^{5}$ cells in $60 \mathrm{~mm}$ dish)에 트립신 처리 후 원심분리하여 수집하였다. 시료를 차가운 PBS로 세척하고, rhodamine intensities를 $5 \mu \mathrm{L}$ 넣고 염색한 후 FACSCalibur flow cytometer에서 측정값을 FL-1 channel로 맞춰 관찰하고 cell Quest pro software로 분석하였다.

\section{추출물 제조 및 western blot 분석}

B8 $(76 \mu \mathrm{M})$ 을 HeLa cells에 함께 처리하거나 처리하지 않은 HeLa cells $\left(1 \times 10^{5}\right.$ cells in $150 \mathrm{~mm}$ dish)의 총 세포 추 출물과 세포질 분획은 $\mathrm{PBS}$ 처리 후 원심분리하여 수집 하였다. 추출물을 $4{ }^{\circ} \mathrm{C}$ 에서 5 분간 $25,000 \mathrm{~g}$ 에서 원심분리 하여 만들어진 상등액의 단백질 함량은 Bradford 단백질 분석으로 측정하였다. 모든 세포 추출물 $(25 \mu \mathrm{g})$ 을 전기영 동하여 nitrocellulose membranes (Schleicher \& Schuell, Keene,

Table 1. Evaluation of cytotoxicity of bispidinone derivatives

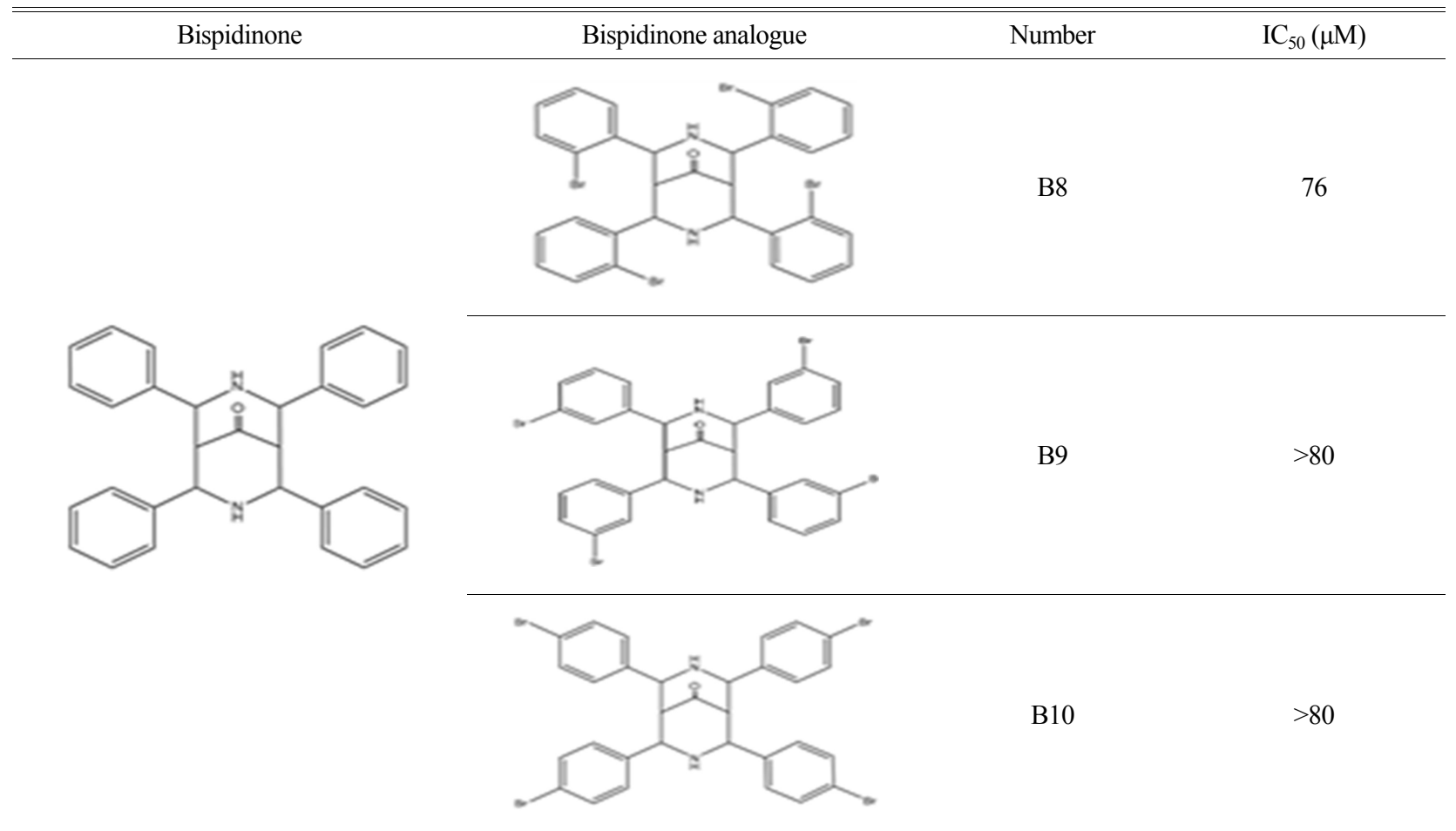




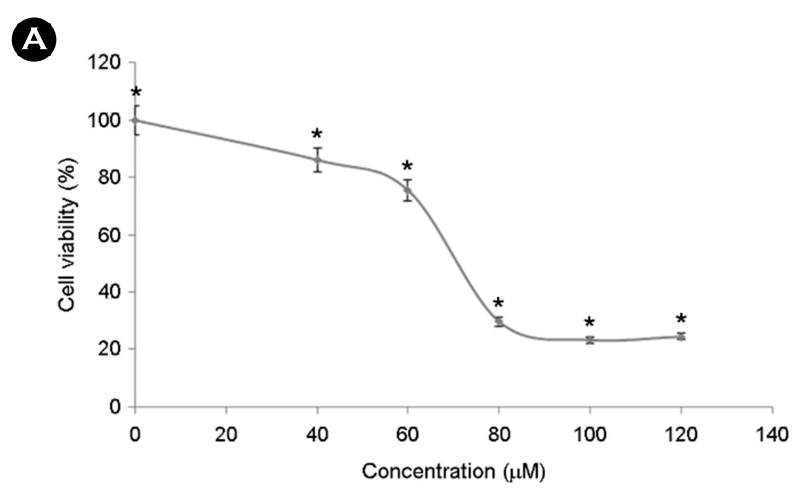

B

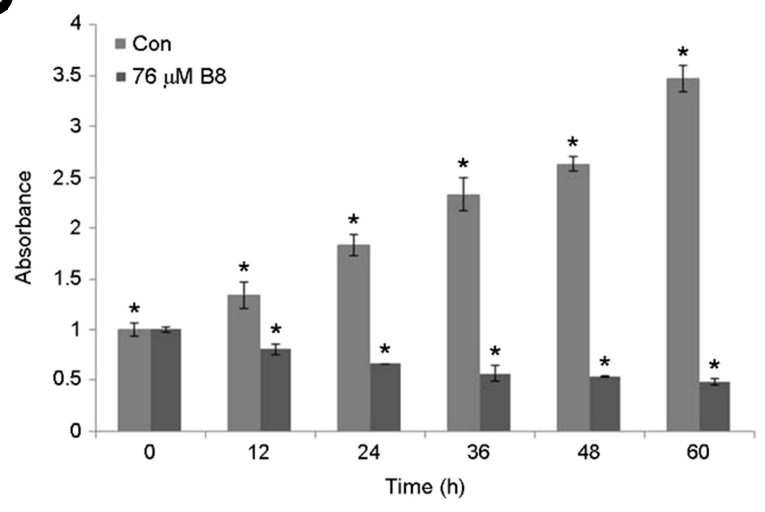

Fig. 1. Effect of $\mathrm{B8}$ on cytotoxicity and proliferation of HeLa cells. (A) HeLa cells were treated with $0,40,80 \mu \mathrm{M}$ of B8 for $48 \mathrm{~h}$. (B) HeLa cells were treated with $76 \mu \mathrm{M}$ of $\mathrm{B} 8$ for various times $(0$, $12,24,36,48,60 \mathrm{~h}$ ). Cell viability was measured by WST- 8 assay. Results are expressed as mean $\pm \mathrm{SD}, \mathrm{n}=3 . * P<0.05$, significantly different from the control at the same level.

$\mathrm{NH}, \mathrm{USA}$ ) 상으로 옮겼다. Bcl-2, procaspase-8, procaspase-9, $\beta$-actin (1: 1,000; Cell Signaling Technology, Danvers, MA, USA), procaspase-3 (1: 300, Santa Cruz Biotechnology, Santa Cruz, CA, USA)와 그리고 $\operatorname{Bax}(1: 1,000, \mathrm{BD}$ Biosciences Pharmingen)가 primary polyclonal antibodies로 사용되었다.

\section{통계 분석}

각 실험은 3 번 반복 실험한 데이터의 평균은 $\pm \mathrm{SD}$ 값 으로 표현하였다. One-way analysis로 통계적 분석을 하였 고, $P<0.05$ 에서 유의한 차이를 보였다. Microsoft Excel 2016 (Roselle, IL, USA)로 통계 분석하고 도표를 그렸다.

\section{결 과}

\section{Bispidinone 유도체들의 세포독성 효과}

다양한 알칼로이드 분자 구조를 갖는 bispidinone 화합
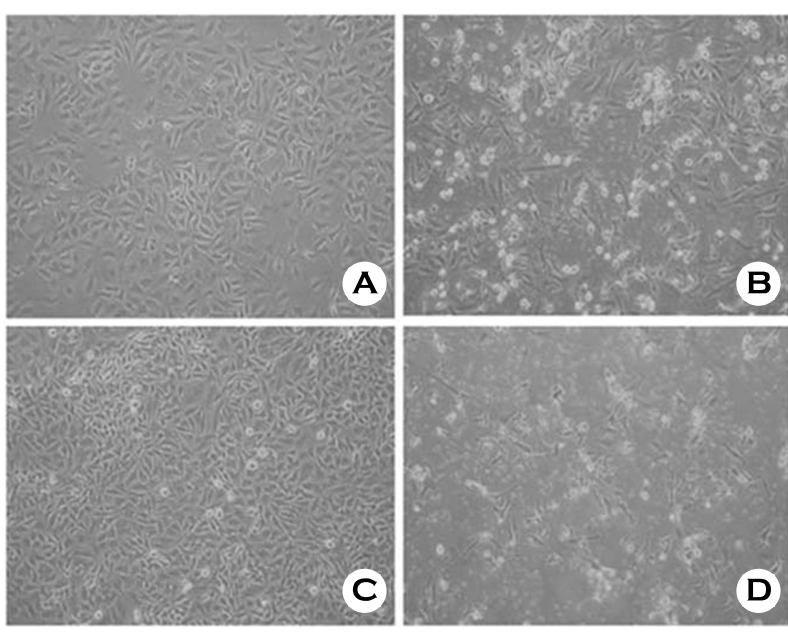

Fig. 2. Induction of morphological change in HeLa cells treated with B8. HeLa cells were untreated with B8 for $24 \mathrm{~h}$ (A) and $48 \mathrm{~h}$ (C). HeLa were treated with B8 $(76 \mu \mathrm{M})$ for $24 \mathrm{~h}(\mathrm{~B})$ and $48 \mathrm{~h}$ (D). Magnification, x160. All the experiments were performed in triplicate and gave similar results.

물(mother compounds)에서 벤젠의 ortho, meta, para 자리에 브롬으로 치환하여 합성한 B8, B9, B10 중 B8 $(2,4,6,8$ tetrakis(2-bromophenyl)-3,7-diazabicyclo[3.3.1]nonan-9-one)의 독성이 가장 강하다는 것을 WST-8 분석을 통하여 확인 하였다(Table 1). 농도(40, 60,80 , 그리고 $120 \mu \mathrm{M})$ 가 증가하 도록 설정하여 $48 \mathrm{~h}$ 동안 배양하면 대조군에 비해 농도가 증가함에 따라 세포의 생존능력이 감소하였다(Fig. 1A). $\mathrm{B} 8$ 이 큰 세포독성 효과를 보여주었으며 $\mathrm{IC}_{50}$ 값이 $76 \mu \mathrm{M}$ 임을 확인하였다. HeLa cells에 B8을 처리하였을 때 같은 농도에서 시간에 따른 세포 증식을 확인을 위해 $0 \sim 60 \mathrm{~h}$ 까지 12 시간 간격으로 설정하고 $\mathrm{IC}_{50}$ 값인 $76 \mu \mathrm{M}$ 로 농도 를 같게 했을 때의 결과(Fig. 1B)를 확인하였다. 대조군은 시간이 증가함에 따라 세포의 증식이 활발히 일어나는 반 면 $\mathrm{B} 8$ 을 처리한 경우 증식하지 않고 점차 감소하는 경향 을 보였다.

\section{$\mathrm{B} 8$ 에 의한 HeLa cells의 형태학적 변화 관찰}

세포의 형태학적 변화는 세포 사멸의 중요한 특징을 나타내기 때문에 B8을 처리한 HeLa cells과 처리하지 않 은 HeLa cells의 변화를 현미경으로 관찰하였다. $\mathrm{B} 8$ 을 처 리하지 않은 $\mathrm{HeLa}$ cells을 culture plates에서 $24,48 \mathrm{~h}$ 동안 의 변화를 관찰하였을 때 $24 \mathrm{~h}$ 에서의 대조군(Fig. 2A)과 $48 \mathrm{~h}$ 의 대조군(Fig. 2C)은 세포 사멸과 관련된 형태가 많이 보이지 않았고 가지를 뺃으며 잘 자라는 반면에, B8을 
(A)

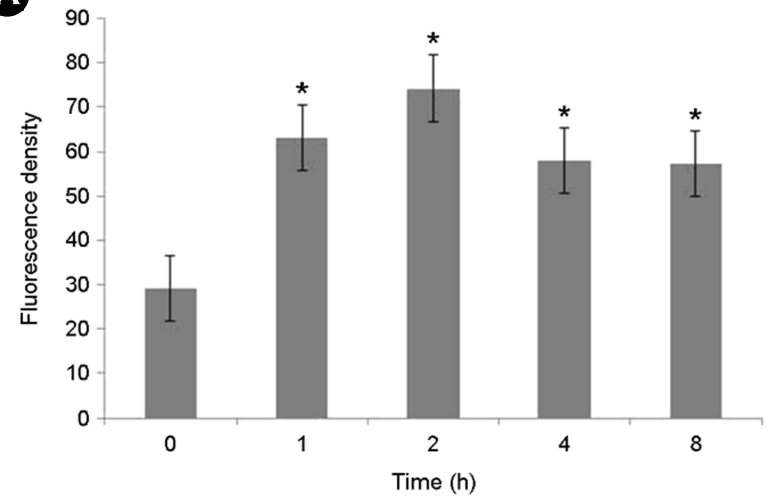

B

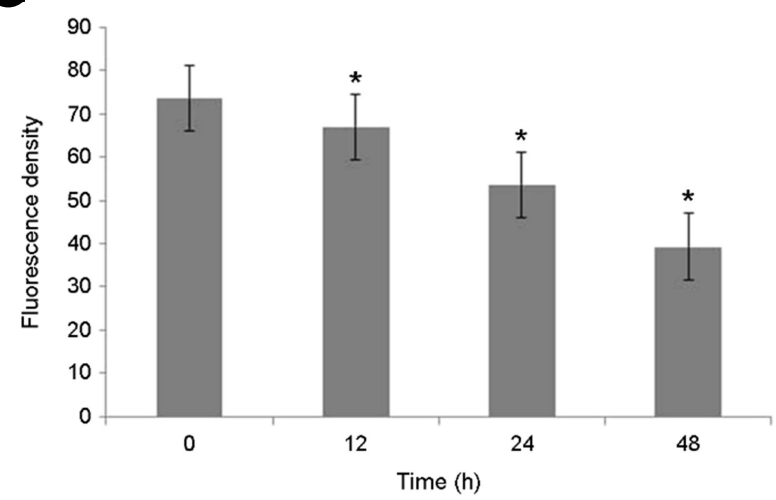

Fig. 3. The effect of $B 8$ on ROS generation and MMP level on HeLa cells. (A) Cells treated with B8 were incubated with DCF-DA. And the intracellular levels of ROS were determined by measuring the level of DCF fluorescence. (B) Cells were incubated with $76 \mu \mathrm{M}$ of B8 for varying lengths of time $(0 \sim 48 \mathrm{~h})$ and then analyzed by JC-1 derived fluorescence. Results are the mean $\pm \mathrm{SD}, \mathrm{n}=3$. $* P<$ 0.05 , means significantly differ from the control at the same level.

$76 \mu \mathrm{M}$ 의 농도로 $24 \mathrm{~h}$ 동안 처리하였을 때(Fig. 2B) 일부의 $\mathrm{HeLa}$ cells이 plates에서 떨어져 부유하고 있었으나 세포 사멸의 특징이 뚜렷하게 보이지 않았다. $48 \mathrm{~h}$ 동안 B8을 $76 \mu \mathrm{M}$ 의 농도로 처리했을 때(Fig. 2D)의 경우 세포 사멸 의 형태학적 특징인 세포들이 수축되고 파괴되는 모습과 많은 세포가 동그란 모양으로 부유하고 있음을 보였다.

\section{$\mathrm{B} 8$ 에 의한 ROS와 MMP levels의 변화}

B8에 의하여 유도되는 ROS level의 변화를 확인하기 위 하여 $\mathrm{B} 8$ 을 $76 \mu \mathrm{M}$ 의 농도로 처리하여 $0,1,2,4,8 \mathrm{~h}$ 동안의 변화를 세포 투과성 염료인 $\mathrm{H}_{2} \mathrm{DCF}-\mathrm{DA}$ 형광 염료를 사용 하여 측정하였다(Fig. $3 \mathrm{~A}$ ). B8을 처리하였을 때 $\mathrm{H}_{2} \mathrm{DCF}-\mathrm{DA}$ 의 평균 형광값은 $29.27 \pm 1.69(0 \mathrm{~h})$ 에서 $74.24 \pm 1.64(2 \mathrm{~h})$ 로 증가하였고 4시간 후 감소하는 경향을 보였다. 이로 인해
A

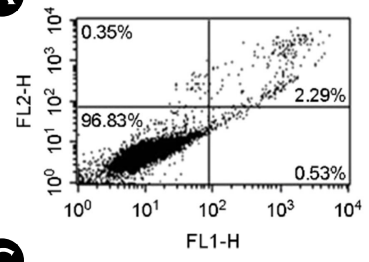

C

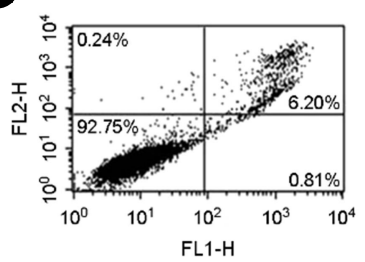

B

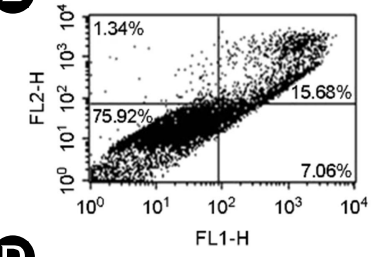

D

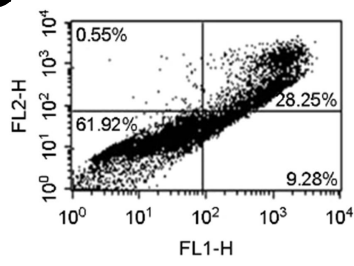

Fig. 4. B8 induced apoptosis in HeLa cells. Untreated with B8 for $24 \mathrm{~h}(\mathrm{~A})$ and $48 \mathrm{~h}(\mathrm{C})$, or treated with $\mathrm{B8}(76 \mu \mathrm{M})$ for $24 \mathrm{~h}$ (B) and $48 \mathrm{~h}$ (D). Data were obtained by flow cytometric analysis of Annexin V-FITC/PI double-staining assay. All the experiments were performed in triplicate and gave similar results.

$\mathrm{B} 8$ 이 ROS의 생성에 영향을 준다는 것을 알 수 있었다. $\mathrm{ROS}$ 의 생성은 미토콘드리아 막 전위의 붕괴와 연관되어 있고 미토콘드리아 막의 탈분극 또한 세포사멸의 중요한 특징으로 여겨지는데, rhodamine $123 \mathrm{dye}$ 의 형광 특성을 이 용해 생체물질이나 그것을 둘러싸는 주변 환경의 성질을 조사하기 위해 사용하여 $\mathrm{MMP}$ 의 손실 여부를 확인하였다 (Fig. 3B). 그 결과 $76 \mu \mathrm{M}$ 의 B8을 처리한 후 평균 rhodamine 123 의 형광이 $73.67 \pm 1.98(0 \mathrm{~h})$ 에서 $66.94 \pm 1.64(12 \mathrm{~h})$, $53.45 \pm 1.87(24 \mathrm{~h})$ 및 $39.25 \pm 1.60(48 \mathrm{~h})$ 로 점차 감소하여 $\mathrm{B} 8$ 이 처리된 $\mathrm{HeLa}$ cells에서 미토콘드리아가 세포 사멸에 관여함을 보였다.

\section{$\mathrm{B} 8$ 에 의한 세포 사멸 유도 여부 확인}

$\mathrm{B} 8$ 에 의한 세포 사멸의 유도 여부를 알아보기 위하여 Annexin V-FITC / PI 이중 염색 분석법을 사용하여 HeLa cells에 B8을 처리하지 않은 세포와 $76 \mu \mathrm{M}$ 의 농도로 처리 한 cells에 대한 $24,48 \mathrm{~h}$ 동안의 변화를 관찰하였다(Fig. 4). Fig. 4에 나와 있는 가로축은 Annexin V-FITC, 세로축은 $\mathrm{PI}$ 를 의미하며 가운데의 중심을 기준으로 오른쪽 아래, 위가 각각 세포사멸 구간(early apoptotic cells (Annexin $\mathrm{V}^{\text {positive }} / \mathrm{PI}^{\text {negative }}$ )과 late apoptotic cells (Annexin $\mathrm{V}^{\text {positive }} / \mathrm{PI}^{\text {positive }}$ ) 이며 왼쪽 위와 아래는 각각 necrosis (Annexin $\mathrm{V}^{\text {negative}}$, $\mathrm{PI}^{\text {positive }}$ )와 live cells (Annexin $\mathrm{V}^{\text {negative }} / \mathrm{PI}^{\text {negative }}$ )을 의미한다. $24 \mathrm{~h}$ 동안 B8을 처리하지 않은 대조군(Fig. 4A)은 B8을 처 리한 HeLa cells (Fig. 4C)에 비해 세포사멸 구간이 약 $20 \%$ 
A



B

Procaspase- 8

$\beta$-actin

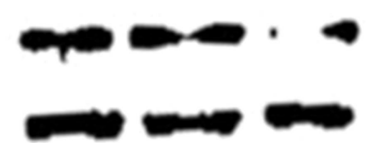

C

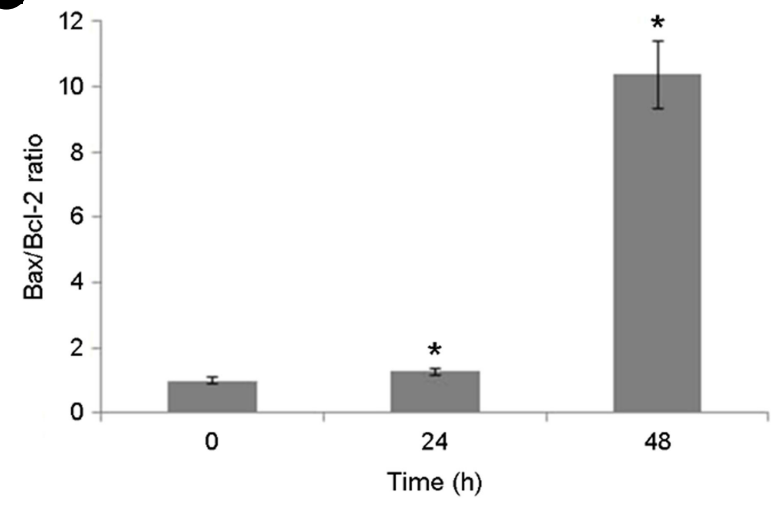

Fig. 5. Induction of protein activation in B8-induced apoptosis on HeLa cells. HeLa cells were treated with $76 \mu \mathrm{M}$ B8 for 0 . 24 and $48 \mathrm{~h}$. the expression of proteins was analyzed by western blotting. (A) Protein expression levels of Bcl-2, Bax, procaspase-9, procaspase-3. (B) Protein expression of levels of procaspase-8. (C) Ratio of $\mathrm{Bax} / \mathrm{Bcl}-2$. Results are expressed as mean $\pm \mathrm{SD}, \mathrm{n}=3$. $* P<0.05$, significantly different from the control at the same level.

증가하는 것을 보였으며, $48 \mathrm{~h}$ 동안 $\mathrm{B} 8$ 을 처리하지 않은 대조군(Fig. 4B)과 B8을 처리한(Fig. 4D) 것의 세포사멸 구 간 차이는 약 $30 \%$ 증가하였다. 이로 인해 HeLa cells에서 $\mathrm{B} 8$ 이 세포 사멸을 유도함을 알 수 있었다.

\section{Western blot 분석}

세포 사멸과 관련되는 단백질들의 발현을 조사하여 $\mathrm{B} 8$ 이 어떤 메커니즘을 통해 세포 사멸을 유도하는지를 western blot analysis을 사용하여 확인하였다(Fig. 5). Fig. $5 \mathrm{~A}$ 에서 $\mathrm{Bcl}-2$ 와 관련된 단백질은 mitochondrial-mediated pathway가 원활하게 일어나기 위해 중요한 역할을 한다 (Gross et al., 1999). Anti-apoptotic protein인 Bcl-2의 발현은 시간이 지남에 따라 감소했으며, pro-apoptotic protein인 $\mathrm{Bax}$ 의 발현은 시간이 지남에 따라 증가하는 경향을 보였 고, procaspases-3, 9의 발현 또한 증가하였다. Bax/Bcl-2 비 율을 확인한 결과 $48 \mathrm{~h}$ 에서 크게 증가하는 것을 확인할 수 있었다(Fig. 5C). Fig. 5A의 결과에 의하면 세포 사멸은 내부 경로로 일어남을 확인하였고, 또한 procaspase-8의 발현(Fig. 5B)이 감소하는 경향을 보임으로써 B8은 Fas signaling apoptosis 경로를 통하여 세포 사멸을 유도할 가 능성도 있음을 확인하였다.

\section{고 찰}

최근에 bispidinone에 대한 암 치료법과 관련된 자료가 발표되었고 이것의 세포독성 효과는 많이 알려져 있으므 로 암을 치료하기 위한 방법으로 쓰일 수 있을 것으로 생각한다(Predebon et al., 2019). Bispidinone에 있는 알칼로 이드 중 비타민 $\mathrm{A}$ 나 흰개미의 페로몬 등의 생물활성을 가지는 디테르펜(diterpene)은 신체에서 혈액 순환을 개선 시켜주며, 심리 안정, 강력한 항산화 작용과 항암 작용을 하는 등 다양한 약리 작용과 정서를 안정시키는데 도움 을 주는 것으로 보고되어 있고 루핀 등과 같은 강력한 생리 작용을 주는 특성을 가지는 알칼로이드가 존재하기 때문에 생물학적으로 관심을 많이 가지게 되었다. B8은 다른 bispidinone 유도체들(B9, B10)보다 낮은 농도에서 $\mathrm{HeLa}$ cells의 증식을 억제하여 B8이 어떤 경로를 거쳐 세 포가 죽음에 이르는지에 대한 사실을 다양한 방법을 사 용하여 세포사멸 유도 경로를 확인하였다(Kiechle and Zhang, 2002; Otsuki et al., 2003).

$\mathrm{HeLa}$ cells의 형태학적 분석에 의하여 B8에 의해 세포 크기가 줄어들었으며 수축과 분열 같은 세포사멸 유형 이 관찰되었다. $\mathrm{ROS}$ 의 생성과 $\mathrm{MMP}$ 를 측정하기 위해 rhodamine 123 염색법을 사용했다. Rh-123 형광물질은 mitochondrial potential에 따라 색이 변하는 성질을 사용하 여 측정하였다. 측정한 결과 $\mathrm{B} 8$ 이 세포 사멸을 유도했으 며, 이는 세포 간 $\mathrm{ROS}$ 의 생성과 $\mathrm{MMP}$ 의 유의한 감소를 매개함을 보였다. 그리고 Annexin V-FITC / PI 이중염색 분 석법을 사용한 결과 $\mathrm{B} 8$ 에 의해 세포 사멸이 일어남을 확 신할 수 있었다.

$\mathrm{HeLa}$ cells에서 B8이 어떤 경로를 통해 세포 사멸을 일 으키는지 알아보기 위해 western blot analysis을 하였다. 
세포사멸 경로에서 중요한 역할을 담당하는 단백질에는 $\mathrm{Bax}$ 와 Bcl-2가 있으며, Bax (pro-apoptotic protein)는 세포 질로 cytochrome c의 방출을 극대화시키고 $\mathrm{Bcl}-2$ (antiapoptotic protein)는 방출을 억제시키는 역할을 담당한다. 본 연구에서 $\mathrm{Bcl}-2$ 의 발현이 점차적으로 감소하고 $\mathrm{Bax}$ 의 발현이 증가하는 것을 확인하였고 $\mathrm{Bcl}-2$ family protein이 세포 사멸을 조절하는 열쇠 역할을 하고 있음을 증명하였 다. 또한 미토콘드리아 내부에 있는 cytochrome c는 Apaf1 과 caspase-9로 인해 apoptosome의 형성을 극대화시키고, caspase-3의 활성을 증가시켜 세포 사멸을 일으킨다(Fulda and Debatin, 2006; Saitoh et al, 2004; Ghobrial et al., 2005). $\mathrm{B} 8$ 은 $\mathrm{ROS}$ 의 생성을 증가시키고 미토콘드리아 막 전위 를 감소시켜 세포 사멸을 촉진시켰다. B8에 의해 caspase cascades가 활성화되어 미토콘드리아가 관여되는 경로를 통하여 세포 사멸이 유도됨을 알 수 있었다. 또한 B8은 procaspase-8의 발현을 감소시켜 외부 경로를 통해 세포 사멸을 일으킬 수 있는 가능성도 확인하였다.

\section{ACKNOWLEDGEMENT}

None.

\section{CONFLICT OF INTEREST}

No a conflict of interest exist in other authors or my institution.

\section{REFERENCES}

Aline MN, Amandine R, Maryame SY, Loïc JC. 2,4-Substituted bispidines as rigid hosts for versatile applications: from $\kappa$ opioid receptor to metal coordination. Dalton Trans. 2019. 48: 16476-16492.

Chan WH, Wu CC, Yu JS. Curcumin inhibits UV irradiationinduced oxidative stress and apoptosis biochemical changes in human epidermoid carcinoma A431 cells. J of Cellular Biochem. 2003. 90: 327-338.

Fleury C, Mignotte B, Vayssiere JL. Mitochondrial reactive oxygen species in cell death signaling. Biochimie. 2002. 84: 131-141.

Fulda S, Debatin KM. Extrinsic versus intrinsic apoptosis pathways in anticancer chemotherapy. Oncogene. 2006. 25: 4798-4811.

Ghobrial IM, Witzig TE, Adjei AA. Targeting apoptosis pathways in cancer therapy. C.A. Cancer J Clin. 2005. 55: 178-194.

Gross A, McDonnell JM, Korsmeyer SJ. BCL-2 family members and the mitochondria in apoptosis. Genes Dev. 1999. 13: 1899
$-1911$.

Jiang CP, et al. Pro-apoptotic effect of tectorigenin on human hepatocellular carcinoma HepG2 cells. World J Gastroenterol. 2012. 18: 1753-1764.

Jaiprakash NS, Abhay SZ, Firoz AK, Indrajeet G, Zahid Z. Synthesis and biological activity of substituted-4,5,6,7-tetrahydrothieno pyridines: a review. Mini Rev Med Chem. 2014. 14: 988-1020.

Kiechle FL, Zhang X. Apoptosis: biochemical aspects and clinical implications. Clin Chim Acta. 2002. 326: 27-45.

Kraus W, Emmerling F, Comba P. Hexadentate bispidine derivatives as versatile bifunctional chelate agents for copper (II) radioisotopes. Bioconjug Chem. 2009. 20: 347-359.

LeBras M, Clement MV, Pervaiz S, Brenner C. Reactive oxygen species and the mitochondrial signaling pathway of cell death Histol Histopathol. 2005. 20: 205-220.

Limon HV, Hai-Yehia A, Levi-Schaffer F. Role of reactive oxygen species (ROS) in apoptosis induction. Apoptosis. 2000. 5: 415 -418 .

Lobrich M, Jeggo PA. The impact of a negligent G2/M checkpoint on genomic instability and cancer induction. Nature Reviews. 2007. 7: 861-869.

Mine EI, Gunger K, Emine S. Antioxidant enzyme activities and malondialdehyde levels related to aging. Clinica Chimica Acta. 2001. 305: 75-80.

Murray A. Cell cycle checkpoints. Curr Opin Cell Biol. 1994. 6: 872-876.

Otsuki Y, Li Z, Shibata MA. Apoptotic detection methods from Morphology to gene. Prog Histochem Cytochem. 2003. 38: 275-339.

Pathak S, Sharma C, Jayaram HN, Singh N. Apoptotic signaling induced by benzamide riboside an in vitro study. Mol Cell Biochem. 2009. 328: 67-73.

Predebon MJ, Bond DR, Brzozowski J, Jankowski H, Deane F, Tarleton M, Shaw AA, McCluskey A, Bowyer MC, Weidenhofer J, Scarlett CJ. The Bispidinone Derivative 3,7Bis-[2-(S)-amino-3-(1H-indol-3-yl)-propionyl]-1,5-diphenyl3,7-diazabicyclo[3.3.1]nonan-9-one Dihydrochloride Induces an Apoptosis-Mediated Cytotoxic Effect on Pancreatic Cancer Cells In Vitro. Molecules. 2019. 24: 524-539.

Pucci B, Kasten M, Giordano A. Cell cycle and apoptosis. Neoplasia. 2000. 2: 291-299.

Saitoh M, Nagai K, Nakagawa K, Yamamura T, Yamamoto S, Nishizaki T. Adenosine induces apoptosis in the human gastric cancer cells via an intrinsic pathway relevant to activation of 
AMP-activated protein kinase. Biochem Pharmacol. 2004. 67: 2005-2011.

Wang C, Youle RJ. The role of mitochondria in apoptosis. Ann Rev Genet. 2009. 43: 95-118.

Ziegler DS, Kung AL. Therapeutic targeting of apoptosis pathways in cancer. Curr Opin Oncol. 2008. 20: 97-103.
https://doi.org/10.15616/BSL.2020.26.4.336

Cite this article as: Lee MG, Kwon R. Anticancer Activity of Bispidinone Derivative by Induction of Apoptosis. Biomedical Science Letters. 2020. 26: 336343. 